\title{
Giving from the heart or from the ego? \\ Motives behind remittances of the second generation in Europe
}

\author{
Tineke Fokkema ${ }^{1 *}$ \\ Eralba Cela ${ }^{2}$ \\ Elena Ambrosetti ${ }^{3}$ \\ ${ }^{1}$ Netherlands Interdisciplinary Demographic Institute (NIDI) \\ P.O Box 11650 \\ 2502 AR The Hague \\ fokkema@nidi.nl \\ ${ }^{2}$ Faculty of Economics \\ Department of Economics and Social Sciences \\ Piazzale Martelli 8, 60121, Ancona, Italy \\ e.cela@univpm.it \\ ${ }^{3}$ Sapienza University of Rome \\ Department of Methods and Models for Economics, Territory and Finance, \\ Via del Castro Laurenziano, 9-00161, Rome, Italy \\ elena.ambrosetti@uniroma1.it
}

*Correspondence address 


\begin{abstract}
The aim of this article is to investigate the remittance behavior of host country-born children of migrants — the second generation — in various European cities. We address the following question: Are second-generation remitters driven more by altruism or by self-interest? Data from "The Integration of the European Second Generation" (TIES) survey are utilized and encompass individuals with at least one migrant parent from Morocco, Turkey or former Yugoslavia. Using logistic models we test different classical theories on microeconomic determinants of remittances and add some additional expectations for the second generation. The results show that those secondgeneration Moroccans, Turks and former Yugoslavs who send money are motivated by two main reasons: emotional attachment to their parents' home country (altruism motive) or to pay people who look after their investments or other material assets that are likely to be part of their preparation for "returning" (self-interest - exchange motive). These two motives are not necessarily exclusive: as part of a well-prepared return, to integrate easily once back "home" it is not only relevant to ensure that people take care of one's investments and other material assets, but also to strengthen social ties and be well-informed about the situation in the country of origin. This interpretation fits closely with the return model, which deserves more attention in the theoretical literature on remittances.
\end{abstract}

Key words: second generation, remittances, altruism, self-interest, European countries 


\section{Giving from the heart or from the ego?}

\section{Motives behind remittances of the second generation in Europe}

\section{Introduction}

The connections between first-generation migrants and their households in the country of origin have been broadly studied by the scholars worldwide. Many of these studies have focused on the analysis of remittances, explaining migrants' transfers behavior — an interpretation that is closely related with the evolution of the theory of migration. The neo-classical migration theory (Harris and Todaro 1970; Sjaastad 1962; Todaro 1969) considers migration as an individual choice in that income-maximizing individuals act in response to geographical differences in the supply and demand for labor, and tends to "disregard other migration motives as well as migrants" belonging to social groups such as households, families and communities” (De Haas 2010, 231). In such a context, remittances do not find a justification. In the 1980s and 1990s, the "New Economics of Labor Migration" (NELM) theory (Stark and Bloom 1985; Taylor 1999) moved beyond the neoclassical model, considering it as too rigid to explain the determinants of migration. The NELM theory no longer views migration as an individual income-maximizing strategy but as a project developed within the family context to spread income risks and overcome local market constraints. In the NELM, remittances represent the household strategy, and in contrast with neo-classical migration theory they are considered as the primary objective of the decision to migrate.

The relationships with family in the home country represent the core element of migratory projects of first-generation migrants (Levitt 2001), but the same cannot automatically be affirmed for second generations: they do not have members of the nuclear family in the parental homeland, unless their parents and/or siblings returned home. This makes it difficult to carry out a one-on-one comparison of remittances behavior across generations. Nevertheless, the transnational lives of the second 
generation and their frequent ongoing visits to the parental homeland allow them to have frequent contacts with relatives or friends back "home".

Over the years, a number of "remittance motives theories" have been developed for first-generation migrants, but there are no specific theories for the second generations. Although some important studies (Leichtman 2005; Levitt 2001; Levitt and Waters 2002) find that transnationalism applies also to subsequent generations, for example in the form of family visits, elder care and remittances (Baldassar et al. 2007; Zontini 2007), the literature on their remittance behavior is still scarce and primarily qualitative in nature. Only a few quantitative studies, mainly North American, have attempted to analyze the main predictors of the remitting behavior of second generations (Bautista 2009; Kasinitz et al. 2008; Lee 2007; Rumbaut 2002). In Europe, several researchers have taken important steps forward in analyzing migrants' children's behavior and identity toward birth and ancestral countries within the broader framework of the transnationalism studies (Beauchemin, Lagrange and Safi 2011; Crul and Schneider 2010; Crul, Schneider and Lelie 2012; Fokkema et al. 2012; King and Christou 2010; Schneider et al. 2012; Thomson and Crul 2007), but thorough research is lacking on the remittance behavior of second generations.

The present article fills this gap in the literature by studying quantitatively and for the first time in the European context the main driving forces behind remittances of second-generation Moroccans, Turks and former Yugoslavs. More particularly, building on the "remittances motives theories" developed for first-generation migrants and proposing additional possible motives for the second generation, we address the following research question: What are the main reasons behind the second generation's remitting behavior, are they driven more by altruism or by self-interest? The article is organized as follows: in the next section we provide a brief overview of the empirical studies on remittances among the second generation, followed by theoretical remittances models in 
Section 3. Section 4 describes the data and methods, and Section 5 reports the results of the regression analyses. Conclusions and discussion are presented in the last section of the article.

\section{Linking second generations to remittances}

The question of whether transnationalism is only a phenomenon among first-generation migrants or also applies to the second generation is controversial. Gans (1997) predicts that transnational ties decrease because of an increasing assimilation process over generations, assuming a negative association between transnationalism and integration in the "host" society; this means that the stronger the integration, the lesser the maintenance of transnational ties. By contrast, Levitt and Glick Schiller (2004) show that integration and transnational practices are simultaneous processes, and Foner (2002) writes that the second generation will be more engaged in transnational practices than the first. Other researchers (Portes et al. 1999; Portes et al. 2002; Guarnizo et al. 2003; Van Dalen et al. 2005; Tamaki 2011; Fokkema et al. 2012) find evidence that transnational ties and integration are complementary and not mutually exclusive, particularly in the case of economic integration: economically integrated individuals have increased cognitive and financial capacity to maintain transnational ties.

Living in transnational social space does not necessarily mean that the second generation maintain strong ties to their ancestral homes (Vickerman 2002). Hence many scholars of the second generation try to identify more accurately the actual involvement in transnational relations, compared to processes of ethnic identification that could be purely symbolic (for example “emotional transnationalism" - Wolf 2002), without reference to specific forms of transnational activities (Kasinitz et al. 2002; Louie 2006). Levitt et al. (2003) differentiate a "comprehensive" transnationalism from a "selective" one, in order to distinguish individuals who retain intensive transnational activities from those who have periodic or occasional ties with the country of origin. 
In the European context, the only study analyzing transnational practices of second-generation Turks, Moroccans and Former Yugoslavs — which are also the core of our analyses — is that of Fokkema et al. (2012). The authors compare the second generation in Europe and the U.S. and individuate two types of transmigrants — selective and comprehensive, the first category being much bigger than the latter. Another study carried out in the European context, particularly in France, is that of Beauchemin et al. (2011), which analyzes the potential connections between integration and different domains of transnationalism, namely political, economic, social and symbolic. The authors find out that not only migrants and their children engage in transnational practices but also segments of the French population; transnationalism is a common phenomenon among migrant populations, and groups of migrants specialize in different practices.

As mentioned above, the relatively few quantitative studies analyzing the main motivations of second-generation remittances are predominantly North American and the primarily studied communities are Latinos and Asians. In her study on the Tongan community in Australia, Lee (2007) finds the transnational ties of the second generation to be not as strong as those of their parents; they are less likely to remit, and if they do, they send less money than their parents. Only a small share of Tongans' second generation send remittances to Tonga, with females more likely to remit than their male counterparts, and the main motivation is represented by parental pressure or by the presence of relatives in Tonga. Other factors supposed to foster transnational ties, such as frequent visits to Tonga and degree of attachment to the parents' home country, have no direct influence on remittances behavior.

In the case of Filipinos in the United States, Bautista (2009) looks at potential gender differences among the second generation, comparing first-generation transnational practices and secondgeneration intentions to remit. She finds that regardless of gender almost all second-generation Filipinos are willing to remit in the future in order to retain their parents' tradition of remitting, even 
if they have never visited the Philippines or do not speak their ethnic language. In conclusion, the emotional and cultural ties to the parental homeland seem to be the main predictors of willingness to remit, bearing in mind that in the Filipino migrants' tradition remittances have an important economic and social role (Clark and Drinkwater 2007; Menjivar et al. 1998).

Kasinitz et al. (2008) focus on the second generation in the New York metropolitan area, analyzing transnational activities, including remittances, in comparison to those of parents. Their results show that the intensity and frequency of engagement in the ancestral country are weaker for the second generation and that the engagement varies across different communities: Dominicans, West Indians and, to a lower extent, South Americans are the more transnational communities, while Chinese and Russians are the less engaged. According to the authors, the lower remittance activity among the young generation is attributed to both the young age of the respondents — in the future they would probably send more money — and the low level of other transnational activities compared to their parents.

Rumbaut's empirical contribution (2002), in the collection edited by Levitt and Water (2002), focuses on the objective and subjective factors that promote or undermine the second-generation attachment to the parental homeland over time. Although not the focus of his analyses, remittances are considered as an objective indicator, including about three out of four respondents. Among the different groups analyzed, Filipinos are the most engaged and the Asians and Chinese the least. The strongest factor influencing remitting behavior is fluency in the ethnic language. More notably, religious involvement, largely overlooked by the literature, is associated with a higher frequency of remittances. Rumbaut finds that life course events strongly affect younger generation behavior, especially when they are called to give economic and emotional support in case of stressful events like a parent's death or illness/disability of a relative. Nevertheless, Rumbaut ends his study with the notion that the how and why of second-generation transnational practices still remains an open 
question that could be answered through "thick" ethnographies rather than "thin" survey data (Rumbaut 2002, 90).

\section{Remittance motives theories}

The main driving forces behind migrants' remittances have been largely analyzed for firstgeneration migrants. The theoretical approach distinguishes between an altruistic motive to remit, pure self-interest motives, and intermediate motivations: enlightened self-interest/tempered altruism. For an excellent overview of those theoretical models, we refer to Rapoport and Docquier (2006).

In the altruistic model the migrant sends remittances to household members in the country of origin because he/she cares about them (Becker 1974). The reasons behind the altruistic behavior are of an emotional and social kind and are aimed at improving the living conditions of the family as well as at preserving and strengthening the ties between remitters and the relatives at home. According to this model there is a positive relation between the amount of remittances and migrants' income, and an inverse relation with the income of the household in the country of origin (Lucas and Stark 1985). Furthermore, altruism decreases gradually over time and with familial distance, as well as with the number of migrants in the same household (Agarwal and Horowitz 2002; Funkhouser 1995). In the altruism model there is a positive relation between probability and amount of remittances, which means that those who are more likely recipients will receive a higher amount of remittances.

If the migrant's behavior is led by a pure self-interest motivation, the remittances could be sent for three reasons. First, remitting behavior can be driven by the aspiration of inheritance. In the case of a bequest motivation, the migrant sends remittances in order to strengthen his/her reputation at 
home and to assure an important role within the family hierarchy. Hence the higher the assets to inherit and the higher the migrant's income, the greater the amount of remittances sent (De la Briere et al. 1997; Hoddinott 1994). Furthermore, remittances are expected to be strongly related to the probability of inheriting and thus negatively related to the degree of risk aversion and familial distance, and to have an inversely U-shaped relation with the number of migrants in the same household (heirs): sharing the inheritance with other migrants means higher competition, which could increase the migrant's remittances, but the likelihood of inheriting is smaller with an increasing number of heirs and this could decrease remittances.

Second, migrants (usually temporary ones) could remit money for an exchange motivation: to invest in assets in the country of origin or to provide for their maintenance, with the relatives left behind acting as agents; or to pay for the services provided by the family at home such as caring of the children left behind (Cox 1987; Cox et al. 1998). According to this model, remittances increase with migrants' income and the number of services provided and either decrease or increase with household income (which is a proxy for the services' prices), depending on the elasticity of migrants' demand for the services provided; remittances will decrease if the migrant's demand is elastic and increase if the demand is inelastic. The latter, however, is an important prediction of the exchange motivation, because it allows discrimination between exchange and altruistic behavior (Rapoport and Docquier 2006). Another remarkable prediction of this model is the negative relation between remittances and a migrant's education, since exchange motivations are typical of temporary migrants, whereas more educated migrants are expected to have a lower propensity to return.

The third pure self-interest model is the strategic one (Stark 1995). The reasons behind remittances are the result of a strategic behavior of high-skilled workers, who want to protect their wages from becoming depressed by the presence of low-skilled migrants. According to this model, migrants' 
wages are based on the average productivity of the pool of migrants to which they belong, because of the lack of information about individual skill levels that keeps employers at the destination country from distinguishing among workers in terms of their productivity. For this reason, skilled migrants send remittances to dissuade the unskilled from migrating. The strategic model predicts that remittances increase with migrants' income and education and decrease with household income, since the strategic behavior aims at reducing the main incentive for migration, represented by the wage differentials between the two countries. Furthermore, remittances are expected to decrease over time because high-skilled workers' skills will increasingly be noticed and valued by employers at the destination.

One of the difficulties in testing both theories — altruism and self-interest — is that it is difficult to distinguish between motivations derived from the two alternative models of remittances behavior, as remittances tend to combine a diverse set of factors and reasons. Besides, altruism and selfinterest may coexist, given that some of their predictors overlap. Lucas and Stark $(1985,904)$ affirm that "[i]n the end one cannot probe whether the true motive is one of caring or more selfishly wishing to enhance prestige by being perceived as caring”. But they suggest a test in order to distinguish the self-interest motivation from the altruistic one: if the remittance behavior is affected by a strong bargaining power of the household (such as the sanctions against migrants), it does not fit with the altruistic model. Thus the prediction is that the greater the household wealth in the country of origin, the higher its bargaining power and the higher the amount of remittances sent by migrants. The prediction of the altruistic model is the opposite: a higher amount of remittances flows to poorer households (Lucas and Stark 1985; Stark and Lucas 1988).

These two extreme motivations (altruism and pure self-interest) do not fully explain migrants' remittance behavior. Lucas and Stark (1985) elaborated an intermediate model in order to better explain the motivation to remit: enlightened self-interest (or tempered altruism), which represents 
an intertemporal, contractual arrangement between migrants and their households in the country of origin (Azam and Gubert 2005; Lucas and Stark 1985; Poirine 1997). According to this model, remittances could satisfy the interests of both migrants and their families left behind. The two basic elements of this contractual arrangement are investment and risk.

In terms of investment, remittances might constitute the repayment with interest of the migration costs or the cost of the migrant's education (Ilahi and Jafarey 1999; Poirine 1997). A better education allows a potential migrant to find a better paid job abroad. The aim of such a family contract is to increase household wealth. The further away the country of origin and the higher the education completed, the higher the costs made by the household and hence the more remittances to be transferred - a potential boon for the family. With regard to the educational effect, it is difficult to distinguish between this model and the altruistic and pure self-interest ones, because both these behaviors also predict a positive relation between remittances and migrants' income, and thus education follows. Nevertheless, Lucas and Stark (1985) suggest that in the investment model the effect of education on the probability and amount of remittances should be higher among the close relatives of the household, such as for the children of the head of the family (familial distance). Another interesting prediction of this model is the inverse U-relation between remittances and household income, since migration is constrained by liquidity and family wealth enables the financing of migration: for wealthy families remittances are expected to decrease.

Remittances could also represent a common household risk-reducing and diversification strategy in less developed countries, where the capital market and the insurance system are insufficient. In particular, households in the rural context allocate one or more family members to a non-correlated labor market (an urban area or abroad, for example) (Stark and Levhari 1982), not to maximize the income but rather to minimize the risk of worsening of the family's economic and social conditions at home. The risks are insured through remittances. Contrary to the other models, remittances are 
not dependent on either the migrant's or the household's income but are more likely to occur when income at origin is more volatile and the household holds sizeable and thus more risky assets. At the same time, the migrant receives support from the household for the costs of migration or during job purchase or unemployment spells. Although remittances as an answer to families' shocks could also be consistent with the altruistic model, there is a basic difference between the two models, represented by the timing variable: according to the altruistic behavior, remittances decrease gradually over time, whereas in the co-insurance model remittances are sent on a relatively irregular basis, without decrease during a given period (when shocks occur) and with a sharp decline after the end of the agreement obligation.

Both the investment and the risk agreements are self-reinforced thanks to the simultaneous coexistence of altruism and at least one type of self-interest motivation that prevents migrants from defaulting. Moreover, the family may possess sanctions that can be used to control the behavior of their migrant members, like depriving them of their rights to inherit, family solidarity, or the right to return, and hence to secure remittances (Lucas and Stark 1985).

Largely building on the work of Rapoport and Docquier (2006), Table 1 presents the expected effects of the main explanatory variables on remittances according to the "remittance motives theories" described above. However, as these theories are developed for first-generation migrants, several theoretical underpinnings are not predicted in the case of second-generation remittances behavior. This holds particularly for the two enlightened self-interest/tempered altruism models. In these models, the direct link between remittances and the family's costs of education and subsequent migration is central, which is difficult to transform to the second generation: they attend school in the "host" country and it is highly unlikely that the contractual agreement between their parents and family will transfer across generations. Consequently, we restrict our attention to test 
the effects of the variables predicted by the altruism and pure self-interest models, with the exception of the effect of households' socioeconomic status, as relevant information is missing.

We hypothesize that the theoretical reasoning and related expected effects of the altruism and pure self-interest models might also hold for the second generation: they may send remittances as an act of mere generosity without any kind of commitment or obligation to relatives or friends in their parents' home country; on the other hand, their behavior could be led by selfish motivation in order to enlarge the likelihood of inheritance, reimburse those who take care of their investments and assets in the country of "origin", or facilitate their intention to "return". We will therefore examine whether the effects of respondents' characteristics are in the predicted direction of the altruism and/or pure self-interest models outlined in the highlighted part of Table 1 .

Besides the rich set of controls and the effort to link to a broad literature on remittances, we have included in our analysis several other new factors, not considered by the previously discussed theories. These factors can be expected to be less or not important for "altruism" motives but are important for "self-interest" motives and vice versa. For example, "emotional attachment" factors (e.g. strong feelings for the country of origin or ethnic group, intense cultural orientation toward the country of origin) are expected to be main predictors of the altruistic motivation. On the other hand, “economic attachment” and return-related factors ${ }^{2}$ (e.g. investment and assets at home, dissatisfaction with the level of equal treatment in the educational system and in the labor market) will affect more strongly the self-interest motivation to remit.

\footnotetext{
${ }^{1}$ Strictly speaking, it is not a return - they are born and raised in the "host" society — but a move to their parents' country of birth. However, for second generation it could be an ontological sense of return to a point of origin, their ethnic homeland (King and Christou 2010a). Therefore, and for the sake of simplicity, we use the term return throughout this article.

2 The literature on second-generation transnationalism also focuses on "roots migration", describing the physical and emotional migration of the second generation to the parents' homeland (Levitt 2009; Wessendorf 2007).
} 


\section{Data and Measurements}

To answer our research question — whether the remitting behavior of the second generation is driven more by altruism or by self-interest — and hence to test the alternative, expected effects of the determinants on remittances, we use survey data from "The Integration of the European Second Generation" (TIES) project, a collaborative and comparative research project on the lives of secondgeneration individuals of Turkish, Moroccan and former Yugoslavian descent in several cities across Europe. The survey, conducted in 2007-2008, collected information on 9,771 individuals aged 18-35, including 3,750 persons belonging to a "native" control group. The countries and cities were selected on extent of ethno-racial segregation and on the basis of contrasting immigration, naturalization and integration policies so that respondents would reflect a wide spectrum of policy contexts. This article presents analyses for cities in Austria (Vienna and Linz), Switzerland (Zurich and Basel), Germany (Berlin and Frankfurt), France (Paris and Strasburg), Spain (Barcelona and Madrid), the Netherlands (Amsterdam and Rotterdam) and Sweden (Stockholm). ${ }^{3}$ In those cities an identical questionnaire was used, making it possible to pool the data sets. Moreover, as the survey was conducted in each city in the same period of time (2007-2008), it is very unlikely that the timing of the global financial crisis and its impact on the 'host' and 'home' countries will differ systematically. The pooled multinational sample is reduced to $\mathrm{N}=4,040$ due to the exclusion of the "native" individuals and missing values on the dependent and independent variables.

\section{Dependent variables}

Respondents were asked whether they sent money to their parents' country of birth in the last five years, and if so, how much money approximately per year. Nearly one fifth, 19\%, of the individuals

\footnotetext{
${ }^{3}$ Because of differences in questionnaire design and restricted access to data, the Belgian cities of Brussels and Antwerp are excluded.
} 
in our sample remitted. For those sending money, no fewer than $54 \%$ transferred less than $€ 500$ and $25 \%$ between $€ 500$ and $€ 1000$, whereas only $9 \%$ remitted more than $€ 2000$ (see Table 2 ). Based on this information, a dummy variable was created indicating whether the person sent remittances $(0=$ no, $1=$ yes $)$.

\section{Independent variables}

Four variables refer to one's socioeconomic status: (1) perceived difficulties with current income, running from 0 = great difficulties to 3 = coping/comfortable (reference group); (2) educational attainment, reflecting the highest level of education respondents had completed by obtaining a qualification or diploma, harmonized across countries, ${ }^{4}$ ranging from $1=$ no school or primary school to $5=$ completed higher education; (3) whether the individual is currently employed $(0=$ no, $1=$ yes); and (4) current or last occupational attainment, coded according to the International Socio-Economic Index of Occupational Status (ISEI; Ganzeboom \& Treiman, 1996), running from 16 (e.g. domestic workers, cleaners and launderers, agricultural and fishery laborers) to 88 (medical doctors).

Number of migrants in the same household is measured by the number of siblings in the family. Presence of parents abroad $(0=$ no, $1=$ yes $)$ is the only opposite indicator we can include for familial distance. Respondents' age (in years) is the proxy for time.

Eight variables refer to emotional attachments: (1) feelings of belonging to parents' home country, ranging from $0=$ very weak/not at all to $4=$ very strong; (2) watching $T V$ channels from parents' home country, running from $0=$ never to $3=$ exclusively; (3) use of internet for information about parents' home country ( 0 = no, 1 = yes); (4) use of ethnic language in family setting, running from 0

\footnotetext{
${ }^{4}$ To make educational attainment comparable across countries, national educational system qualifications are transformed into UNESCO's ISCED categories (Schneider 2008).
} 
$=$ always using the language of the parents' country of origin to $1=$ always using the language of the country of residence $;{ }^{5}(5)$ participation in organizations of ethnic signature $(0=$ no, $1=$ yes $){ }^{6}$ (6) co-ethnic friendship, representing the number of co-ethnic friends amongst the three best friends (score: $0-3)$; (7) partner status, comparing those having a first- or second-generation partner $(0=$ no, $1=$ yes) to those having a partner of another ethnicity (including a "native" partner) or no partner; and (8) whether the individual visited the parents' home country for family reasons in the last five years $(0=$ no, $1=$ yes $)$.

Economic attachment is measured by the variable investment, i.e. whether or not the individual invested money in business or real estate in the parents' home country in the past five years $(0=$ no, $1=$ yes $)$.

Three variables refer to return-related variables: (1) return migration intention is measured by the question: "Do you intend to live in your parent's country of birth in the future for a period of one year or longer?" with the following response categories: $0=$ certainly not, $1=$ possibly, $2=$ likely, and 3 = certainly. (2) level of satisfaction with career, with three categories, $1=$ as or better than expected (reference group), $2=$ worse than expected, and $3=$ far worse than expected; and (3) extent of satisfaction with level of education, with the following response categories: $0=$ completely dissatisfied, $1=$ mostly dissatisfied, $2=$ partly dissatisfied, $3=$ mostly satisfied, and $4=$ completely satisfied (reference group). The last two variables measure subjective elements of one's structural integration. They are included as return-related factors because of their link with the failure-success binary of the migrant's strategies (Heckmann 2005). The direction of their effects,

\footnotetext{
${ }^{5}$ Respondents were asked which language they use, if applicable, with their siblings, mother, father, and current/last partner. The response categories range from "mostly the language of parents' country of origin" to "mostly the language of the country of residence". The scores on these four items are converted into one summary scale, reflecting the degree of use of ethnic language in a family setting.

${ }^{6} \mathrm{~A}$ list of organizations was presented to the respondents. After indicating whether or not they participated in each organization in the past year, they were asked in which of these organizations the activities are mostly oriented toward the ethnic community.
} 
however, cannot be predicted a priori. According to the neoclassical approach, return migration is mainly interpreted as the result of an integration failure in the host country; migrants who feel that they failed to improve their lives in the host county are more likely to return. The New Economics of Labor Migration, on the other hand, considers return migration as the outcome of success; returnees are those who achieved their goals.

Finally, several socio-demographic characteristics that are generally known to have an effect on remitting behavior are included as control variables in the analyses. The first one is gender, with man as reference group. Another variable controlled for is religiosity, comparing those who declare "no religion" with "strict/social Muslim", "symbolic/identificational Muslim", and "other religion" (e.g. Catholics, Protestants, and Orthodox Christians). ${ }^{7}$ Clark and Drinkwater (2001: 23) argue that religiosity is of importance in remitting behavior: they explain differences in remitting behavior among ethnic group through religious affiliation, stressing that Islam emphasizes "brotherhood across international frontiers". Furthermore, the migrant group variable is included, identifying the members of our target groups and differentiating between second-generation Turks (reference group), Moroccans and former Yugoslavs. To examine whether remitting depends on the distance between "host" and "home" country, the variable geographical distance (between the current city of residence and the biggest city in the parents' home country, in kilometers, log scale) was created. Finally, to examine whether remitting varies across different policy regimes, the dummy variable multicultural policies, distinguishing those participating countries with a more multicultural approach (Sweden, the Netherlands) from those with a more exclusionist or assimilationist approach (Austria, Germany, France, Spain, Switzerland), was created (Castles and Miller 2009;

\footnotetext{
${ }^{7}$ The two distinct groups of Muslims are constructed on the basis of four items of religious behavior (fasting, eating halal food, daily prayer, and visiting the mosque) and a self-identifying question as Muslim. "Strict Muslims" answer "most of the time" or "always" on the four items on religious behavior, while "Social Muslims" only fasting and eating halal food "most of the time" or "always" and the other two items on religious behavior "less often". "Symbolic Muslims" report on one or more of the four items on religious behavior "less often", while "Identificational Muslims" report "never" on the four items on religious behavior but identify themselves as Muslim.
} 
Koopmans 2008). Cross-country comparisons are highly relevant as states are critical actors in shaping the options for transnational behavior (Levitt and Jaworsky 2007; Waldinger and Fitzgerald 2004): in countries with a predominantly multicultural approach, maintaining strong transnational ties is not an impediment for societal engagement and integration in the host country, while an exclusionary or assimilation approach will lead to a trade-off between transnationalism and integration.

As a way of summary, Table 2 provides descriptive information on each of the independent variables.

\section{--- TABLE 2 ABOUT HERE ---}

\section{Analytical approach}

In order to identify the variables that best predicted the remitting behavior of the second generation in Europe, and particularly whether remitting is more driven by altruism or by self-interest, logit regression analyses were carried out. No multicollinearity issues occurred. For ease of interpretation, the results are reported in odds ratios. Table 3 presents the results of this analysis.

We ran five different models on the likelihood of remitting. In Model 1 the control variables are included. Model 2 also incorporates respondents' socioeconomic status variables (perceived income, educational attainment, employed, occupational attainment), with an expected positive effect according to both the altruism and the self-interest theories (though a negative effect of education according to the exchange model), and "number of siblings", "presence of parents abroad" and "age" with a different expected effect between remittance motives models in question. In the next two models, besides the control variables, the variables capturing emotional attachment (Model 3) and economic attachment and return-related factors (Model 4) are taken into account. As 
mentioned above, these variables are new elements we add to the conventional ones in order to shed more light on the dominance of each type of remitting motive: emotional attachments are expected to be main predictors in case of all altruistic motives, while economic attachment and return-related factors are more in line with pure self-interest behavior. The final model (Model 5) includes all variables. In the models we clustered the standard errors by country to account for correlation across individuals within the same country.

\section{Results}

When only the control variables are considered (Model 1), religiosity influences the remittance behavior: so-called strict/social and symbolic/identificational Muslims as well as those with another religion are more likely to remit than non-religion individuals. Second-generation former Yugoslavs are more likely to remit than those of Turkish origin, whereas second-generation Moroccans have a lower likelihood of remitting. Geographical distance has a clear positive effect: the greater the distance, the more likely they are to send remittances. Gender and multicultural or assimilationist policies of the participating countries have no effect on remitting behavior.

Model 2 partially confirms the expected positive effect of socioeconomic status according to both the altruism and pure self-interest models. Being employed increases the likelihood to remit, although educational attainment does not substantially influence one's remitting behavior; no negative (as expected by the exchange model) or positive effects (expected by the other models) were found. However, having major problems to make ends meet does decrease the likelihood of remitting. Number of siblings positively affects the likelihood to remit, contradicting expectations of the altruism, exchange and strategic models. We did not find evidence for the expected inverted U-shaped relationship of the inheritance model either, as the square of the number of siblings (data not presented here) is not significant. The presence of parents abroad, as opposite indicator of 
familial distance, enormously increases the likelihood to remit, an effect which has been raised by both the altruism and the inheritance model. Contrary to all remittance motives models, the likelihood to send remittances increases with age (time). This finding is probably the result of the narrow age range of the sample (18-35), the oldest of whom are more likely to have a better socioeconomic position, in line with the finding of Kasinitz et al. (2008). A further explanation could be that an older child is more likely to have the responsibility of taking care of parents and/or relatives in the ancestral home.

In line with the altruism model, emotional attachment substantially affects the likelihood to remit (Model 3). Respondents who more often watch TV channels from the parents' home country, use the Internet for information about the parents' home country, speak the ethnic language in a family setting, participate in organizations of ethnic signature or visit parents' home country for family reasons, as well as those with a first- or second-generation partner, are more likely to send remittances. No positive effect was found on feelings of belonging to parents' home country and coethnic friendships. Emotional attachment seems to be gender-related, as in Model 3 a significantly higher likelihood of remitting is found for men. Moreover, once we account for respondents' degree of emotional attachment, the previously observed higher likelihood of remitting among strict/social Muslims becomes insignificant, as does the lower likelihood of sending remittances among Moroccans.

Model 4 shows that the investment and return variables also have a strong positive effect on remitting behavior, which is accordance with the exchange model. Respondents who have invested in the parents' country of origin and those who express an intention to return are much more likely to remit. Caution is needed when interpreting these findings though, as endogeneity is likely to play a role: part of the money sent to the homeland through remittances can be used for investments, perhaps as preparation for a return. Like the objective measure of educational attainment, the 
subjective counterpart does not affect the second generation's remitting behavior. Moreover, level of satisfaction with one's career does not substantially influence remitting behavior either.

The final model (Model 5) includes all independent variables. Most of the variables that are significant in one of the earlier models remain significant in the full model. Exceptions are the insignificant difference between non-religion individuals on the one hand and the two distinct types of Muslims and those with another religion on the other, and between second-generation Turks and Moroccans (both attributable to the association with emotional attachment, as previously indicated), as well as the effect of perceiving great difficulties with income, watching TV channels from the parents' home country, use of ethnic language in the family setting, and having a second-generation partner.

\section{--- TABLE 3 ABOUT HERE ---}

\section{Alternative explanations of results}

As noted above, the problem of potential endogeneity applies mainly to the investment variable. Investment in the parental home country may increase the likelihood of remitting, sending money to those who look after their investment, but investment is subject to reverse causality as well: it is likely that some of the second generation only remit for investment purposes. In accordance with the fact that the majority of the theoretical predictions do not link with the investment decision, however, Table 2 shows that the percentage of investors is small (4.9\%) compared to the percentage of remitters (18.6\%). Accordingly, although the majority of investors (66\%) also remit, most remitters do not invest (81 against 19\%). Nevertheless, to examine whether the inclusion of the investment variable has resulted in serious biases in the parameter estimates for the other independent variables, we re-ran the analyses with exclusion of the investment variable. The results clearly show hardly any changes in the other variables' effects (results not presented, but available 
upon request). Two issues are worthy to note: in the model without the investment variable, secondgeneration Moroccans are significantly (at 5\%-level) more likely to remit than their Turkish counterparts and, as expected (given the relationship between investment and "return"), the effects of the return-intention dummies are stronger.

We also conducted several additional analyses to check the robustness of our results. Firstly, a number of alternative clustering specifications were tested. Specifically, instead of clustering by survey country we clustered by survey city, pair survey country-migrant group, and pair survey city-migrant group. Secondly, to control for the unobservable time-invariant differences between groups of individuals, we performed (conditional) fixed effects logistic regression for each of the four clustering specifications. Thirdly, to deal with the small number of clusters we repeated all the regression analyses by using the bootstrap procedure. These three additional kinds of analyses show that virtually identical results are obtained (results not presented, but available upon request). Finally, we ran the final model of Table 3 for each ethnic group separately. Table 4 shows that the results are quite consistent and robust, pointing at least to the same direction. Regardless of ethnicity, the second generation's likelihood to send money increases with geographical distance to the parental country, when being employed and older, and with emotional attachment, investments and intention to return. Nevertheless, some non-significant factors in the pooled analysis appear to be very important determinants of remitting for one of the three ethnic groups. Second-generation Moroccans living with a second-generation partner of the same national origin are less likely to remit than those with no or a native partner. Among the second-generation of Moroccan or former Yugoslavian descent a clear gender difference can be observed: Moroccan men are less prone to remit than their female counterparts, while the opposite holds for former Yugoslavs. Additionally, compared to non-religious individuals, former non-Muslim Yugoslavs are more likely to remit. Finally, former Yugoslavs who are not satisfied with their level of education have a lower likelihood to remit. 


\section{Conclusion and Discussion}

What are the main reasons behind the remitting behavior of the second generation: are they more driven by altruism or by self-interest? This is a new and unexplored topic in the European context. We answered this research question by examining in a comparative approach and through quantitative data the main predictors for remittance among second-generation Turks, Moroccans and former Yugoslavs residing in several cities across Europe. More specifically, different theories on microeconomic determinants of remittances, developed exclusively for first-generation migrants, as well as additional possible determinants were tested. We built on the review of the theoretical debate, analyzed by Rapoport and Docquier (2006), who suggest several motivations behind remitting behavior of first-generation migrants, such as pure altruism, bequest and the use of remittances to obtain a wide range of services, and more intricate motives such as family loan repayment and insurance. Besides examining the effect of similar factors as being important for first-generation migrants, additional new factors - economic and emotional attachment, as well as return-related factors — were included as possible further explanations for the remittances behavior among the second generation.

According to our results, two types of motives seem to dominate the remitting behavior of the second generation: altruism, i.e. sending money because of an emotional attachment to parents' home country, and exchange motivations, i.e. remitting to those people who look after their investments or other material assets that are likely to be part of their preparation for returning. Whether the presence of these two types of motives implies different groups of remitters is questionable. First of all, remitting is usually not driven by a single motivation but is rather the 
result of a mixture of different motives. Second, a higher likelihood to remit due to strong emotional bonds is not necessarily driven by altruistic feelings only, it could also be attributable to selfinterest, i.e. strengthening social ties and staying well-informed about the situation of the ancestral country, in view of asset accumulation, bequest decisions, or in order to make it easier to integrate once back "home", as Brown (1994; 1997) and Ahlburg and Brown (1998) found among Pacific Islander first-generation migrants. These latter interpretations are close to the return model stated by Lucas and Stark (1985), which seems to be overlooked in the theoretical literature. According to this model, remittances could be sent in order to invest in housing, livestock or other assets, or to enhance social prestige and preserve and strengthen social ties with relatives and/or friends, in preparation for a dignified permanent return to the community of origin. Due to its potential relevance in explaining the motivation behind remittances, also for the second generation, we recommend that future researchers include the return model within the theoretical framework of the remittances' theory.

As mentioned above, the theoretical models of remittances are exclusively developed for firstgeneration migrants; to our knowledge, no previous studies have tried to test these models for migrants' children. Children of migrants grow up in cultural settings where norms governing everyday life are shaped by a continuous mutual exchange of people, ideas, norms, practices and goods from the ancestral home and the country of settlement (Levitt 2001). Their engagement in transnational processes is often assumed to be influenced by the family and by religious and coethnic organizations, which institutionalize transnational social networks and fuel a sense of membership. Such a context generates both opportunities and responsibilities; the former could materialize in social and economic mobility, the latter could create expectations and social pressure that may result in children's involvement through material and emotional support (Baldassar et al. 2007; Zontini 2007). Indeed, according to our results, religiosity (for former Yugoslavs), use of ethnic language in the family setting (Moroccans and former Yugoslavs), participation in 
organizations of ethnic signature (Turks) and having a first-generation partner (for Turks and former Yugoslavs) are important determinants of the likelihood to remit. Our results also show that the second generation's remittances behavior is influenced by other emotional bonds — visiting parents' home country and communication tools (TV and internet) that create bridges between countries - as well as by their nationality (former Yugoslavs most likely to remit) and geographic distance between the residence country and the parents' country.

An interesting result of our analysis is the link between remittances of the second generation on the one hand, and investments and their intention to migrate to their ethnic home country on the other; remittances are the result not only of an altruistic behavior aimed at caring about the welfare of parents at "home" (as is the case with Moroccans and former Yugoslavs, for example), but also the desire to invest in the ancestral country. It would be interesting to further investigate the main reasons behind the return intention: does the second generation mainly migrate to their parents' country of origin because of an integration failure in the "host" country, a mismatch between an actual and expected job, or, as Levitt (2009) pointed out, due to their prospects for social mobility generated by the transnational social and economic space of their everyday life? In their study on second-generation "returnees" to Greece, King and Christou (2010b) highlight the accessibility of a productive and successful return to their parental homeland, facilitated by age, high education levels, bilingualism, and kinship and friendship networks in Greece, created and reinforced during childhood periods spent in the parental homeland. According to the authors the ability to move between "host" and "home" countries and cultures facilitates their adaptation process to the changed Greek society, whereas the return of their parents at an older age could be "problematic or a failure" (King and Christou 2010b,116). However, for migrants' descendants the "return intention" to the parental homeland could be neither a return nor a new migration, but just a way of living back and forth as they have done so far throughout their life. Constraints, such as professional barriers in the developed countries, and opportunities, generated by multiple cross- 
border bonds, could become the incentive to undertake such a strategy of transnational life. Furthermore, mutual support within transnational communities could represent the stepping stone for socioeconomic mobility toward investments in the ancestral home. As scholars point out, with regard to the high-skilled second generation, investing in the ancestral homeland (Foner 2002) or maintaining transnational ties through financial support (Levitt 2002) could be attractive and represent social and economic mobility, or risk diversification.

It is worth mentioning that the second generation is the root of the vast cross-border diasporas that have likely fostered international trade and investment over the last several decades. Cross-border ties, especially non-economic ties such as ethnic and extended family networks, could represent a competitive advantage in overcoming market informal barriers, facilitating trade and identifying business opportunities, as argued by several works of Rauch (1996, 1999, 2001; Rauch and Trindade 2002) and underlined by Levitt (2009:1226) in relation to the second generation: "Just as membership in tightly-knit ethnic communities in a host country embeds children in powerful, often protective social networks that create opportunities as well as obligations, so even indirect, almost-by-osmosis membership in the homeland community is also a potential source of power, information and support”.

The interpretation of the driving forces behind second-generation remittances is not straightforward. In the framework of the remittances models, discriminating tests require a large number of variables, as also Rapoport and Docquier (2006) highlight in their conclusion. In the present article, however, quite a large number of variables have been considered, even in addition to conventional ones. Nevertheless, no information was available about the socioeconomic status of those left behind, which would allow us to better discriminate between the models. Also, because of the lack of data on to whom second-generation Turks, Moroccans and former Yugoslavs remitted, examination of the effect of "familial distance" was far from optimal. Moreover, parents" homeland 
orientation can be driven by many other factors not considered in this study for lack of information, such as the necessity to offer economic and emotional support for emergencies during the life course of parents who retired back home (Baldassar et al. 2007; Zontini 2007), or as Rumbaut (2002) suggests in his analyses, stressful life events like a parent's death or illness/disability of a relative. Such events shape children's attachment toward relatives at home by assuming moral responsibilities of maintaining ties to relatives and perpetuating their parental bonds in the ancestral home. Hence future efforts to develop theoretically-driven remittances models among the second generation, containing and testing a broad set of factors differentiating among the models, are highly recommended.

This study is only a first step, and many efforts are still needed to develop theories specifically for the second generation, with a link to other theories on remittances, integration, ethnic networks, trade and investments. A strategic challenge for future studies is to consider the transnational location of the determinants of remittances by simultaneously examining senders' and receivers' remittances data as well as migration contexts, taking into account that policies at receiving and ancestral countries might play an important role too in determining behavior through remittances and returning. Our findings suggest the complexity of the nature of such transnational ties. We firmly believe that a mixed-method approach, combining both quantitative and qualitative research, would surmount some of the shortcomings and enable further in-depth exploration of motives beyond remittances. Lastly, since ties with the ancestral country - as both responsibilities/obligations and opportunities - vary over time, a longitudinal approach to the study of remittances is an important challenge for a comprehensive understanding of remitters' strategies.

\section{Acknowledgements}


We would like to express our sincerest thanks to the two anonymous reviewers for their highly constructive comments and suggestions, which have significantly improved the article from its earlier version. Our special thanks also go to Andrea Presbitero for providing comments and support both on the earlier draft of the article and during the final revision process. 


\section{References}

Agarwal, R., \& Horowitz, A.W. (2002), Are international remittances altruism or insurance? Evidence from Guyana using multiple-migrant households. World Development, 30(11), 2033-2044.

Ahlburg, D.A., \& Brown, R.P.C. (1998), Migrants' intentions to return home and capital transfers: A study of Tongans and Samoans in Australia. Journal of Development Studies, 35(2), 125-51.

Azam, J.P., \& Gubert, F. (2005), Those in Kayes: The impact of remittances on their recipients in Africa. Revue économique, 56, 1331-1358.

Baldassar L., Baldock, C., \& Wilding, R. (2007), Families caring across borders migration, ageing and transnational caregiving. Houndmills: Palgrave Macmillan.

Bautista, J. (2009), Generational differences in remittance practices of Filipino Americans. M.A. thesis, California State University, Long Beach. http://gradworks.umi.com/1472261.pdf.

Beauchemin, C., Lagrange, H., \& Safi, M. (2011), Transnationalism and Immigrant Assimilation in France: Between Here and There?, Document de travail (172), Paris : INED, $22 \mathrm{p}$. http://www.ined.fr/fichier/t_publication/1544/publi_pdf1_172.pdf.

Becker, G.S. (1974), A theory of social interactions. Journal of Political Economy, 82, $1063-1093$.

Brown, R.P.C. (1994), Migrants' remittances, savings and investments in the South Pacific. International Labour Review, 133(3), 348-367.

Brown, R.P.C. (1997), Estimating remittance function for Pacific Islands migrants, World Development, 25(4), 613-626.

Castles, S., \& Miller, M.J. (2009), The age of migration: International population movements in the modern world. Fourth edition. New York: The Guildford Press. 
Clark, K., \& Drinkwater, S. (2001), An investigation of household remittance behaviour. The School of Economics Discussion Paper Series, No. 114, http://www.socialsciences.manchester.ac.uk/disciplines/economics/research/discus sionpapers/pdf/Discussion_Paper_0114.pdf.

Clark, K., \& Drinkwater, S. (2007), An investigation of household remittance behavior: Evidence from the United Kingdom. The Manchester School, 75(6), 717-741.

Cox, D. (1987), Motives for private income transfers. Journal of Political Economy, 95(3), 508-546.

Cox, D., Eser, Z., \& Jimenez, E. (1998), Motives for private transfers over the life cycle: An analytical framework and evidence for Peru. Journal of Development Economics, 55(1), 57-80.

Crul, M., \& Schneider, J. (2010), Comparative integration context theory: Participation and belonging in new diverse European cities. Journal of Ethnic and Racial Studies, 33(7), 1249-1268.

Crul, M., Schneider J., \& Lelie, F. (2012), The European Second Generation Compared. Does the Integration Context Matter? Amsterdam: Amsterdam University Press.

De Haas, H. (2010), Migration and development: A theoretical perspective. International Migration Review, 44(1), 227-264.

De la Briere, B., De Janvry, A., Lambert, S., \& Sadoulet, E. (1997), Why do migrants remit? An analysis for the Dominican Sierra. Discussion Paper 37, Washington, DC, FCND.

Fokkema, T., Lessard-Phillips, L., Bachmeier, J.D., \& Brown, S.K. (2012), The link between the transnational behaviour and integration of the second generation in European and American cities: Does the context of reception matter? Nordic Journal of Migration Research, 2(2): 111-23. 
Foner, N. (2002), Second-generation transnationalism, then and now. In P. Levitt \& M. C. Waters (eds), The changing face of home: The transnational lives of the second generation (pp. 242-252). New York: Russell Sage Foundation.

Funkhouser, E. (1995), Remittances from international migration: A comparison of El Salvador and Nicaragua. Review of Economics and Statistics, 77(1), 137-146.

Gans, H.J. (1997), Toward a reconciliation of "assimilation" and "pluralism": The interplay of acculturation and ethnic retention. International Migration Review, 31(4), 875-892.

Ganzeboom, H.B.G., \& Treiman, D.J. (1996), Internationally comparable measures of Occupational Status for the 1988 International Standard Classification of Occupations. Social Science Research, 25, 201-239.

Guarnizo, L., Portes, A., \& Haller, W. (2003), Assimilation and transnationalism: Determinants of transnational political action among contemporary migrants. American Journal of Sociology, 108(6), 1211-1248.

Harris, J., \& Todaro, M. (1970), Migration, unemployment and development: A twosector analysis. American Economic Review, 60(1), 126-142.

Heckmann, F. (2005), Integration and integration policies. Bamberg: European Forum for Migration Studies.

Hoddinott, J. (1994), A model of migration and remittances applied to Western Kenya. Oxford Economic Papers, 46(3), 459-476.

Ilahi, N., \& Jafarey, S. (1999), Guest-worker migration, remittances and the extended family: Evidence from Pakistan. Journal of Development Economics, 58(2), 485512.

Kasinitz, P., Waters, M.C., Mollenkopf, J.H., \& Anil, M. (2002), Transnationalism and the children of immigrants in contemporary New York. In P. Levitt \& M.C. Waters 
(eds), The changing face of home: The transnational lives of the second generation (pp. 96-122). New York: Russell Sage Foundation.

Kasinitz, P., Mollenkopf J.H., Waters, M.C., Holdaway, J. (2008), Inheriting the city:

The children of immigrants come of age. New York: Russell Sage

Foundation/Cambridge: Harvard University Press.

King, R., \& Christou, A. (2010a), Diaspora, migration and transnationalism: Insights from the study of second-generation 'returnees'. In R. Bauböck \& T. Faist (eds), Diaspora and transnationalism: Concepts, theories and methods (pp. 167-183). Amsterdam: Amsterdam University Press.

King, R., \& Christou, A. (2010b), Cultural geographies of counter-diasporic migration: Perspectives from the study of second-generation 'returnees' to Greece. Population, Space and Place, 16(2), 103-119.

Koopmans, R. (2008), Tradeoffs between equality and difference: Immigrant integration, multiculturalism, and the welfare state in cross-national perspective. Berlin: Social Science Research Center Berlin (WZB discussion paper; SP IV 2008-701).

Lee, H. (2007), Transforming transnationalism: Second generation Tongans overseas. Asian and Pacific Migration Journal, 16(2), 157-178.

Leichtman, M.A. (2005), The legacy of transnational lives: Beyond the first generation of Lebanese in Senegal. Ethnic and Racial Studies, 28(4), 663-686.

Levitt, P. (2001), The transnational villagers. Berkeley: University of California Press. Levitt, P.(2002), The ties that change: Relations to the ancestral home over the life cycle. In P. Levitt \& M.C. Waters (eds), The changing face of home: The transnational lives of the second generation (pp. 341-366). New York: Russell Sage Foundation. 
Levitt, P. (2009), Roots and routes: Understanding the lives of the second generation transnationally. Journal of Ethnic and Migration Studies, 35(7), 1225-1242.

Levitt, P., DeWind, J., \& Vertovec, S. (2003), International perspectives on transnational migration: An introduction. International Migration Review, 37(3), $565-575$

Levitt, P., \& Glick Schiller, N. (2004), Conceptualizing simultaneity: A transnational social field perspective on society. International Migration Review, 38(3), 10021039.

Levitt, P., \& Jaworsky, B.N. (2007), Transnational migration studies: Past developments and future trends. Annual Review of Sociology, 33, 129-156.

Levitt, P., \& Waters M.C. (eds) (2002), The changing face of home: The transnational lives of the second generation. New York: Russell Sage Foundation.

Louie, V. (2006), Second generation pessimism and optimism: How Chinese and Dominicans understand education and mobility through ethnic and transnational orientations. International Migration Review, 40(3), 537-572.

Lucas, R.E.B., \& Stark, O. (1985), Motivations to remit: Evidence from Botswana. Journal of Political Economy, 93(5), 901-918.

Menjivar, C., Da Vanzo, J., Greenwell, L., \& Valdez, R.B. (1998), Remittances behavior among Salvadoran and Filipino Immigrants in Los Angeles. International Migration Review, 32(1), 97-126.

Poirine, B. (1997), A theory of remittances as an implicit family loan arrangement. World Development, 25(4), 589-611.

Portes, A., Guarnizo, L.E., \& Landolt, P. (1999), The study of transnationalism: Pitfalls and promise of an emergent research field. Ethnic and Racial Studies, 22(2), 217237. 
Portes, A., Haller, W.J., \& Guarnizo, L.E. (2002), Transnational entrepreneurs: An alternative form of immigrant economic adaptation. American Sociological Review, 67(2), 278-298.

Rapoport, H., \& Docquier, F. (2006), The economics of migrants: Remittances. In J. Mercier-Ythier \& S.C. Kolm (eds), Handbook on the economics of reciprocity, giving and altruism (pp. 1135-1198). Handbook series edited by K. Arrow and M. Intriligator.

Rauch, E.J. (1996), Trade and search: Social capital, sogo shosha, and spillovers, NBER Working Paper, no.5618.

Rauch, E.J. (1999), Networks versus markets in international trade. Journal of International Economics, 48, 7-35.

Rauch, E.J. (2001), Business and social networks in international trade. Journal of Economic Literature, Vol. XXXIX, 1177-1203.

Rauch, E.J., \& Trindade V. (2002), Ethnic Chinese networks in international trade. The Review of Economics and Statistics, 84(1), 116-130.

Rumbaut, R. (2002), Severed or sustained attachments? Language, identity, and imagined communities in the post immigrant generation. In P. Levitt \& M.C. Waters (eds), The changing face of home: The transnational lives of the second generation (pp. 43-95). New York: Russell Sage Foundation.

Schneider, S.L. (ed.) (2008), The International Standard Classification of Education (ISCED-97): An evaluation of content and criterion validity for 15 European countries. Mannheimer Zentrum für Europäische Sozialforschung, University of Mannheim, Germany.

Schneider, J., Fokkema, T., Matias, R., Stojčić, S., Ugrina, D., \& Vera-Larrucea, C. (2012), Identities: Urban belonging and intercultural relations. In M. Crul, J. Schneider \& F. Lelie (eds), The European Second Generation Compared: Does the 
Integration Context Matter? Amsterdam: Amsterdam University Press.Sjaastad, L.A. (1962), The costs and returns of human migration. Journal of Political Economy, 70(5), 80-93.

Stark, O. (1995), Altruism and beyond. Cambridge: Cambridge University Press.

Stark, O., \& Bloom, D.E. (1985), The new economics of labour migration. American Economic Review, 75(1), 191-196.

Stark, O., \& Levhari, D. (1982), On migration and risk in LDCs. Economic Development and Cultural Change, 31, 191-196.

Stark, O., \& Lucas R.E. (1988), Migration remittances and the family. Economic Development and Cultural Change, 36, 465-481.

Tamaki, E. (2011), Transnational home engagement among Latino and Asian Americans: Resources and motivation. International Migration Review, 45(1), $148-173$.

Taylor, J.E. (1999), The new economics of labour migration and the role of remittances in the migration process. International Migration, 37(1), 63-86.

Todaro, M.P. (1969), A model of labour migration and urban unemployment in less developed countries. American Economic Review, 59(1), 139-148.

Van Dalen, H.P., Groenewold, G., \& Fokkema, T. (2005), The effect of remittances on emigration intentions in Egypt, Morocco, and Turkey. Population Studies, 59(3), 375-392.

Vickerman, M. (2002), Second generation West Indian transnationalism. In P. Levitt \& M.C. Waters (eds), The changing face of home: The transnational lives of the second generation (pp. 341-366). New York: Russell Sage Foundation.

Waldinger, R., \& Fitzgerald, D. (2004), Transnationalism in question. American Journal of Sociology, 109, 1177-1195. 
Wessendorf, S. (2007), 'Roots migrants': Transnationalism and 'return' among secondgeneration Italians in Switzerland, Journal of Ethnic and Migration Studies, 33(7), $1083-1102$.

Wolf, D.L. (2002), There's no place like "'home': Emotional transnationalism and the struggles of second-generation Filipinos. In P. Levitt \& M.C. Waters (eds), The changing face of home: The transnational lives of the second generation (pp. 255294). New York: Russell Sage Foundation.

Zontini, E. (2007), Continuity and change in transnational Italian families: The caring practices of second-generation women. Journal of Ethnic and Migration, 33(7), 1103-11. 
Table 1. Summary of the predicted effects of several explanatory variables on remittances

\begin{tabular}{|c|c|c|c|c|c|c|}
\hline \multirow[b]{3}{*}{$\begin{array}{l}\text { •Household's } \\
\text { socioeconomic status }\end{array}$} & \multirow[t]{2}{*}{ Altruistic } & \multicolumn{3}{|c|}{ Pure self-interest } & \multicolumn{2}{|c|}{$\begin{array}{l}\text { Enlightened self-interest/ } \\
\text { tempered altruism }\end{array}$} \\
\hline & & Inheritance & Exchange & Strategic motive & Investment & $\begin{array}{l}\text { Risk/Co- } \\
\text { insurance }\end{array}$ \\
\hline & - & + & $\begin{array}{l}+(\text { but }- \text { for } \\
\text { inelastic demand })\end{array}$ & 0 & $\cap$ & 0 \\
\hline $\begin{array}{l}\text {-Migrant's } \\
\text { socioeconomic status }\end{array}$ & + & + & $\begin{array}{l}+(\text { but }- \text { for } \\
\text { education })\end{array}$ & + & + & 0 \\
\hline $\begin{array}{l}\text {-Number of migrants in } \\
\text { same household }\end{array}$ & - & $\cap$ & 0 & 0 & 0 & 0 \\
\hline •Distance & - (familial) & - (familial) & 0 & 0 & + (geographical) & 0 \\
\hline -Time & - (linear) & 0 & 0 & - & 0 & $\begin{array}{l}0 \text { (but sharp } \\
\text { decline after } \\
\text { contractual } \\
\text { obligation ends) }\end{array}$ \\
\hline $\begin{array}{l}\text {-Emotional attachment } \\
\text { (excl. close family) }\end{array}$ & + & 0 & 0 & 0 & & \\
\hline -Economic attachment & 0 & 0 & + & 0 & & \\
\hline - Return-related factors & 0 & 0 & + & 0 & & \\
\hline
\end{tabular}

Note. The two different colors distinguish between expectations based on classical theories and our three additional expected effects. 
Table 2. Descriptive statistics of the dependent and independent variables $(N=4,040)$

\begin{tabular}{|c|c|c|}
\hline & $\%$ & $\bar{M}$ \\
\hline \multicolumn{3}{|l|}{ Remittances } \\
\hline Remitting & 18.6 & \\
\hline \multicolumn{3}{|l|}{ Amount of money: } \\
\hline Less than $€ 500$ & 55.4 & \\
\hline$€ 500-1000$ & 25.8 & \\
\hline$€ 1000-2000$ & 10.1 & \\
\hline More than $€ 2000$ & 8.7 & \\
\hline \multicolumn{3}{|l|}{ Control variables } \\
\hline Man & 48.8 & \\
\hline \multicolumn{3}{|l|}{ Religion: } \\
\hline Muslim - strict/social & 30.1 & \\
\hline Muslim - symbolic/identificational & 31.0 & \\
\hline Other religion & 12.7 & \\
\hline No religion & 26.2 & \\
\hline \multicolumn{3}{|l|}{ Migrant group: } \\
\hline Turks & 53.3 & \\
\hline Moroccans & 19.8 & \\
\hline Former Yugoslavs & 27.0 & \\
\hline Geographical distance (log) & & 7.3 \\
\hline Resident of country with multicultural integration policy & 33.7 & \\
\hline \multicolumn{3}{|l|}{ Migrant's socioeconomic status } \\
\hline \multicolumn{3}{|l|}{ Perceived difficulties with income: } \\
\hline Great difficulties & 4.7 & \\
\hline Regularly difficulties & 8.6 & \\
\hline Sometimes difficulties & 19.0 & \\
\hline Coping/Comfortable & 67.8 & \\
\hline Educational attainment (1-5) & & 3.4 \\
\hline Employed & 65.4 & \\
\hline \multicolumn{3}{|l|}{ Number of migrants in the same household } \\
\hline Number of siblings (0-18) & & 2.5 \\
\hline \multicolumn{3}{|l|}{ Familial distance } \\
\hline Parents abroad & 6.5 & \\
\hline \multicolumn{3}{|l|}{ Time } \\
\hline Age (18-35) & & 24.4 \\
\hline \multicolumn{3}{|l|}{ Emotional attachment (excl. close family) } \\
\hline Feelings of belonging to parents' home country $(0-4)$ & & 2.9 \\
\hline Watching TV channels from parents' home country $(0-3)$ & & 0.6 \\
\hline Use of internet for information about parents' home country & 22.0 & \\
\hline Use of ethnic language in family setting $(0-1)$ & & 0.4 \\
\hline Participation in organizations of ethnic signature & 22.2 & \\
\hline Co-ethnic friendship (0-3) & & 1.5 \\
\hline \multicolumn{3}{|l|}{ Partner: } \\
\hline First-generation partner & 16.4 & \\
\hline Second-generation partner & 9.1 & \\
\hline Native or no partner & 74.6 & \\
\hline Visiting parents' home country for family reasons & 58.9 & \\
\hline \multicolumn{3}{|l|}{ Economic attachment and return-related factors } \\
\hline Investment & 4.9 & \\
\hline \multicolumn{3}{|l|}{ Return migration intention: } \\
\hline Certainly not & 54.2 & \\
\hline Possibly & 23.7 & \\
\hline Likely & 7.1 & \\
\hline Certainly & 4.7 & \\
\hline Does not know & 10.3 & \\
\hline \multicolumn{3}{|l|}{ Satisfaction with career: } \\
\hline Far worse than expected & 6.5 & \\
\hline Worse than expected & 16.4 & \\
\hline As or better than expected & 77.1 & \\
\hline Satisfaction with level of education: & & \\
\hline Completely dissatisfied & 14.6 & \\
\hline Mostly dissatisfied & 24.0 & \\
\hline Partly satisfied & 20.6 & \\
\hline Mostly satisfied & 25.4 & \\
\hline Completely satisfied & 15.3 & \\
\hline
\end{tabular}


Table 3. Effects (odds ratios) of variables on likelihood of sending remittances among the second generation in selected TIES cities $(N=4,040)$, standard errors clustered by country

\begin{tabular}{|c|c|c|c|c|c|}
\hline Model: & 1 & 2 & 3 & 4 & 5 \\
\hline \multicolumn{6}{|l|}{ Control variables } \\
\hline Man & 1.13 & 1.09 & $1.26 *$ & 1.01 & 1.04 \\
\hline Muslim - strict/social & $2.56 * * *$ & $3.23 * * *$ & 1.28 & $1.85 * * *$ & 1.33 \\
\hline Muslim - symbolic/identificational & $2.01 * * *$ & $2.29 * * *$ & $1.29 * *$ & $1.63 * * *$ & 1.28 \\
\hline Other religion & $1.83 *$ & $1.74 *$ & $1.44 *$ & $1.71 *$ & 1.38 \\
\hline Former Yugoslavs & $2.17 * *$ & $2.21 * *$ & $2.19 * * *$ & $2.42 * * *$ & $2.57 * * *$ \\
\hline Geographical distance $(\log )$ & $2.80 * * *$ & $2.76 * * *$ & $2.87 * * *$ & $3.29 * * *$ & $3.65 * * *$ \\
\hline Resident of country with multicultural integration policy & 1.24 & 1.13 & 1.23 & 1.32 & 1.23 \\
\hline \multicolumn{6}{|l|}{ Migrant's socioeconomic status } \\
\hline \multicolumn{6}{|l|}{ Perceived difficulties with income (ref. great difficulties) } \\
\hline Employed & & $1.57 * * *$ & & & $1.70 * * *$ \\
\hline \multicolumn{6}{|l|}{ Number of migrants in the same household } \\
\hline Number of siblings & & $1.06 * * *$ & & & $1.03 * *$ \\
\hline \multicolumn{6}{|l|}{ Familial distance } \\
\hline Parents abroad & & $2.73 * *$ & & & $2.57 * *$ \\
\hline \multicolumn{6}{|l|}{ Time } \\
\hline Age & & $1.08 * * *$ & & & $1.06 * * *$ \\
\hline First-generation partner & & & $3.54 * * *$ & & $2.32 * * *$ \\
\hline Second-generation partner & & & $1.71 * *$ & & 1.24 \\
\hline Visiting parents' home country for family reasons & & & $1.72 *$ & & $1.64 * *$ \\
\hline \multicolumn{6}{|l|}{ Economic attachment and return-related factors } \\
\hline Investment & & & & $10.25 * * *$ & $7.26 * * *$ \\
\hline \multicolumn{6}{|l|}{ Return migration intention (ref. certainly not) } \\
\hline Possibly & & & & $1.66 * * *$ & $1.55 * *$ \\
\hline Likely & & & & $2.51 * * *$ & $2.17 * *$ \\
\hline Certainly & & & & $2.55 * * *$ & $2.53 * * *$ \\
\hline Does not know & & & & 1.30 & 1.26 \\
\hline \multicolumn{6}{|l|}{ Satisfaction with career (ref. as or better than expected): } \\
\hline Far worse than expected & & & & 1.32 & 1.37 \\
\hline Worse than expected & & & & 1.10 & 0.97 \\
\hline \multicolumn{6}{|l|}{ Satisfaction with level of education (ref. completely satisfied) } \\
\hline Completely dissatisfied & & & & 0.87 & 0.82 \\
\hline Mostly dissatisfied & & & & 0.94 & 0.82 \\
\hline Partly satisfied & & & & 1.05 & 0.84 \\
\hline Mostly satisfied & & & & 1.01 & 0.88 \\
\hline Pseudo $\mathrm{R}^{2}$ & 0.038 & 0.093 & 0.115 & 0.119 & 0.203 \\
\hline
\end{tabular}


Table 4. Effects (odds ratios) of variables on likelihood of sending remittances among secondgeneration Turks, Moroccans and former Yugoslavs in selected TIES cities $(N=4,040)$, standard errors clustered by country

\begin{tabular}{|c|c|c|c|}
\hline Model: & $\begin{array}{c}(1) \\
\text { Turks } \\
(N=2,153)\end{array}$ & $\begin{array}{c}(2) \\
\text { Moroccans } \\
(N=798)\end{array}$ & $\begin{array}{c}(3) \\
\text { Former Yugoslavs } \\
(N=1,089)\end{array}$ \\
\hline \multicolumn{4}{|l|}{$\overline{\text { Control variables }}$} \\
\hline Man & 0.87 & $0.89 * * *$ & $1.95 * * *$ \\
\hline \multicolumn{4}{|l|}{ Religion (ref. no religion): } \\
\hline Muslim - strict/social & 1.17 & 1.57 & 1.87 \\
\hline Muslim - symbolic/identificational & 1.06 & 2.02 & 1.32 \\
\hline Other religion & 0.54 & & $1.87 * * *$ \\
\hline Geographical distance (log) & $5.51 * * *$ & $3.62 * * *$ & $3.87 * * *$ \\
\hline Resident of country with multicultural integration policy & 1.17 & & \\
\hline \multicolumn{4}{|l|}{ Migrant's socioeconomic status } \\
\hline \multicolumn{4}{|l|}{ Perceived difficulties with income (ref. great difficulties) } \\
\hline Regular difficulties & 1.84 & 0.59 & 3.73 \\
\hline Sometimes difficulties & $1.89 *$ & 0.64 & 4.16 \\
\hline Coping/comfortable & 2.10 & 0.73 & 2.41 \\
\hline Educational attainment & $1.06^{*}$ & 1.05 & $0.85^{*}$ \\
\hline Employed & $1.71 * * *$ & $1.84 * * *$ & $1.53 * *$ \\
\hline \multicolumn{4}{|l|}{ Number of migrants in the same household } \\
\hline Number of siblings & 0.99 & $1.07 * * *$ & 1.03 \\
\hline \multicolumn{4}{|l|}{ Familial distance } \\
\hline Parents abroad & 1.66 & $4.02 * *$ & $3.43 *$ \\
\hline \multicolumn{4}{|l|}{ Time } \\
\hline Age & $1.05 * * *$ & $1.03 * *$ & $1.12 * * *$ \\
\hline \multicolumn{4}{|l|}{ Emotional attachment (excl. close family) } \\
\hline Feelings of belonging to parents' home country & 1.10 & 0.83 & 1.03 \\
\hline Watching TV channels from parents' home country & 1.11 & $1.10 * *$ & 0.71 \\
\hline Use of internet for information about parents' home country & $1.43 * * *$ & $0.81 *$ & $3.29 * * *$ \\
\hline Use of ethnic language in family setting & 0.97 & $2.84 * * *$ & $1.61 * *$ \\
\hline Participation in organizations of ethnic signature & $1.71 * *$ & 1.60 & 1.09 \\
\hline Co-ethnic friendship & 1.02 & 1.21 & 1.00 \\
\hline \multicolumn{4}{|l|}{ Partner (ref. native or no partner) } \\
\hline First-generation partner & $2.54 * * *$ & 1.67 & $2.47 * *$ \\
\hline Second-generation partner & 1.35 & $0.50 * * *$ & 1.56 \\
\hline Visiting parents' home country for family reasons & $1.53 *$ & $1.19 * *$ & $2.96 * * *$ \\
\hline \multicolumn{4}{|l|}{ Economic attachment and return-related factors } \\
\hline Investment & $7.83 * * *$ & $7.03 * * *$ & $7.87 * * *$ \\
\hline \multicolumn{4}{|l|}{ Return migration intention (ref. certainly not) } \\
\hline Possibly & 1.29 & $2.58 * * *$ & $1.82 * *$ \\
\hline Likely & 1.81 & $2.74 * *$ & $2.15^{*}$ \\
\hline Certainly & $1.95^{*}$ & $9.94 * * *$ & $2.06 * * *$ \\
\hline Does not know & 1.08 & $1.73 * * *$ & 1.22 \\
\hline \multicolumn{4}{|l|}{ Satisfaction with career (ref. as or better than expected): } \\
\hline Far worse than expected & $1.60 *$ & 0.65 & $1.49 *$ \\
\hline Worse than expected & 1.10 & 0.59 & $0.81 *$ \\
\hline \multicolumn{4}{|l|}{ Satisfaction with level of education (ref. completely satisfied) } \\
\hline Completely dissatisfied & 0.95 & 1.06 & $0.44 * *$ \\
\hline Mostly dissatisfied & 0.98 & 1.85 & $0.24 * * *$ \\
\hline Partly satisfied & 0.93 & 1.00 & $0.47 * * *$ \\
\hline Mostly satisfied & 0.92 & 0.81 & $0.66^{*}$ \\
\hline Pseudo $\mathrm{R}^{2}$ & 0.190 & 0.255 & 0.297 \\
\hline
\end{tabular}

$* * * p<.001 ; * * p<.01 ; * p<.05$ 